\title{
The avifauna of the North Selangor peat-swamp forest, West Malaysia
}

\author{
KANG NEE and LEE PHENG GUAN
}

\section{Summary}

The North Selangor peat-swamp forest occupies an area of about 75,000 ha and has been extensively logged for timber. Of the six sites surveyed, three were located in regenerating or selectively logged areas and contained a higher proportion of forest-dependent species of birds than the other three, which had been extensively cleared by logging and for agriculture. The presence of the nearby Kuala Selangor Nature Park should not diminish the conservation value of the peat-swamp forest, at least where the avifauna is concerned, as their avifauna complement one another.

\section{Introduction}

Peat-swamp forests are found extensively in South-East Asia, occurring on the flat coastal plains on east Sumatra, Borneo and West Malaysia (MacKinnon and MacKinnon 1986, Prentice and Parish 1992). The original extent was estimated to occupy 17 million ha in Indonesia, 1.5 million ha in Sarawak and 0.5 million ha in West Malaysia (Whitmore 1986). Peat-swamp forests are important habitats for large mammals, primates, crocodiles and an avifauna that is unlike that found in other forest types, and they have significant ecological and socioeconomic value, e.g. hydrological regulation and commercial timber (Prentice and Parish 1992). Threats to peat-swamp forests include logging, land-clearing for agriculture, forest fires and excessive drainage (Prentice and Parish 1992).

About $49 \%$ of the original area of peat-swamp forest in West Malaysia remains, but this is inadequately protected and greater efforts are required for its conservation (MacKinnon and MacKinnon 1986). A proposal has been made to conserve three areas of peat-swamp forest in south-east Pahang (90,000 ha), north Selangor (75,000 ha) and Tasek Bera (4,120 ha) (Prentice and Parish 1992).

The North Selangor peat-swamp forest, located $\mathrm{C} .3^{\circ} 30^{\prime} \mathrm{N} 101^{\circ} 20^{\prime} \mathrm{E}$ (see Figure 1), is classified as a mixed peat-swamp forest (sensu Wyatt-Smith 1959). It has been heavily logged for timber but recommendations have been made for the establishment of a forest sanctuary for wildlife in the east-central section of the forest, and for the extension of the boundaries of the subtending Sungei Dusun Game Reserve over the north-east part of the forest to conserve the particular biota of the peat-swamp (Prentice and Aikanathan 1989). Previous studies on the fauna of the North Selangor peat-swamp forest dealt mainly with the birds and mammals (e.g. Prentice and Aikanathan 1989), and fish (Davies and Abdul- 


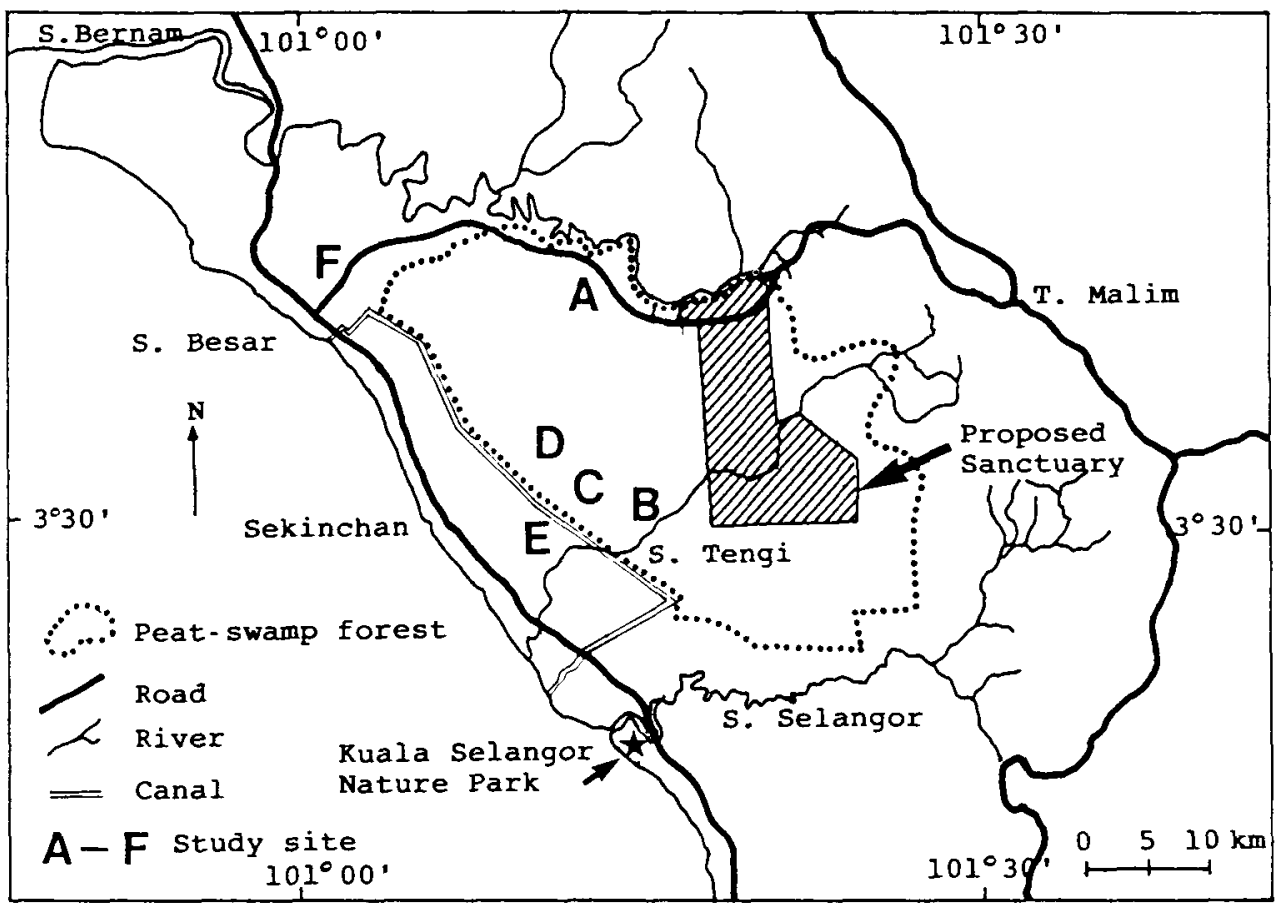

Figure 1. The location of the North Selangor peat-swamp forest and study sites (from Prentice and Aikanathan 1989).

lah 1989). In this study, we describe the relative abundance of bird species in different areas of the peat-swamp forest in relation to the degree of disturbance caused by logging.

\section{Methods and description of study sites}

The study was conducted from 17 to 20 June 1991. Six study sites representing different habitats in and around the peat-swamp forest (see Figure 1) were sampled using a simplified line transect method. The transects were surveyed on foot or from a vehicle or boat travelling at approximately $5 \mathrm{~km}$ per hour. Birds sighted were identified and counted. Owing to the short length of our stay, we did not standardize the time of sampling at the various sites but counted birds throughout different times of the day from o6h3o to 19 h4o.

Site A was a c. $30 \mathrm{~km}$ long transect along the wooded edge of the peat-swamp forest, comprising moderately tall trees with dense undergrowth, small areas of clear-felled forest and occasional blackwater ponds and streams. Site B consisted of a c. $20 \mathrm{~km}$ stretch of riparian habitat along Sungei Tengi, comprising thick undergrowth with moderately tall stands of Macaranga puncticulata interspersed with patches of clear-felled forest. The transect at site C was c. $2 \mathrm{~km}$ in length and forms part of a logging railway with scattered tall trees and moderate undergrowth on either side, with a large patch of clear-felled forest. Site $\mathrm{D}$ was c.10 $\mathrm{km}$ in length and is part of a dirt track extending into the peat-swamp 
forest that is used by heavy logging vehicles for extracting timber; the surrounding forest was highly disturbed with few tall trees, and consisted mainly of low secondary forest trees, shrubs and undergrowth. Site E included areas adjacent to an irrigation canal with disturbed peat-swamp forest on one side and rice paddies on the other; the transect was c. $10 \mathrm{~km}$ long and located on the forested side of the irrigation canal. Site F was a c. $20-\mathrm{km}$ transect which consisted mainly of the rural countryside north-west of the peat-swamp forest with a mosaic of villages, rice paddies and other agricultural land and large stretches of disturbed scrubland. Although site F was situated outside the peat-swamp proper, it was selected so that a range of disturbed peat-swamp habitats was included in our surveys. We classified sites $A, B$ and $C$ as wooded habitats and sites $D, E$ and $F$ as open-country habitats.

\section{Results}

Species composition and numbers

Seventy species of birds were sighted during the surveys. The checklist and number of individuals of each species observed at each study site are presented in the Appendix. Information about the principal habitat requirements of the birds was based on Wells (1985). Our list included 32 species dependent extensively or exclusively on lowland mixed evergreen forest (LMEF), of which two species, the Arctic Warbler Phylloscopus borealis and the Black Drongo Dicrurus macrocercus, are non-breeding winter migrants; five species dependent extensively or exclusively on mangroves; and 33 species not listed as forest birds. The latter two groups will be loosely referred to as non-LMEF species. Those birds which are found primarily in forest or around the forest edges will be collectively referred to as LMEF species.

\section{Habitat structure and species composition}

Figure 2 shows that of the 27 species of birds sighted in wooded areas (sites A, $\mathrm{B}$ and $\mathrm{C}$ ), 23 (or 85\%) were LMEF species. In contrast, open-country habitats (sites D, E and F) contained a higher proportion of non-LMEF ( 18 or $86 \%$ ) than LMEF species (three or $14 \%$ ). Of the nine LMEF species seen in open-country or in both wooded and open-country habitats, five were classified as forest-edge birds by Wells (1985) and four were seen flying over the open-country habitat towards the swamp forest. The 20 non-LMEF species that were seen in wooded or in both habitat types were mainly sighted around the edges or clearings of our study sites.

\section{Discussion}

LMEF species that were not recorded in the checklist of Prentice and Aikanathan (1989) but were sighted in the wooded habitats in this study include the Banded Woodpecker Picus miniaceus and Moustached Babbler Malacopteron magnirostre. Non-LMEF species newly recorded in the wooded habitats include Spotted Dove Streptopelia chinensis, Collared Kingfisher Halcyon chloris, Black Drongo 


\section{NUMBER OF \\ SPECIES}

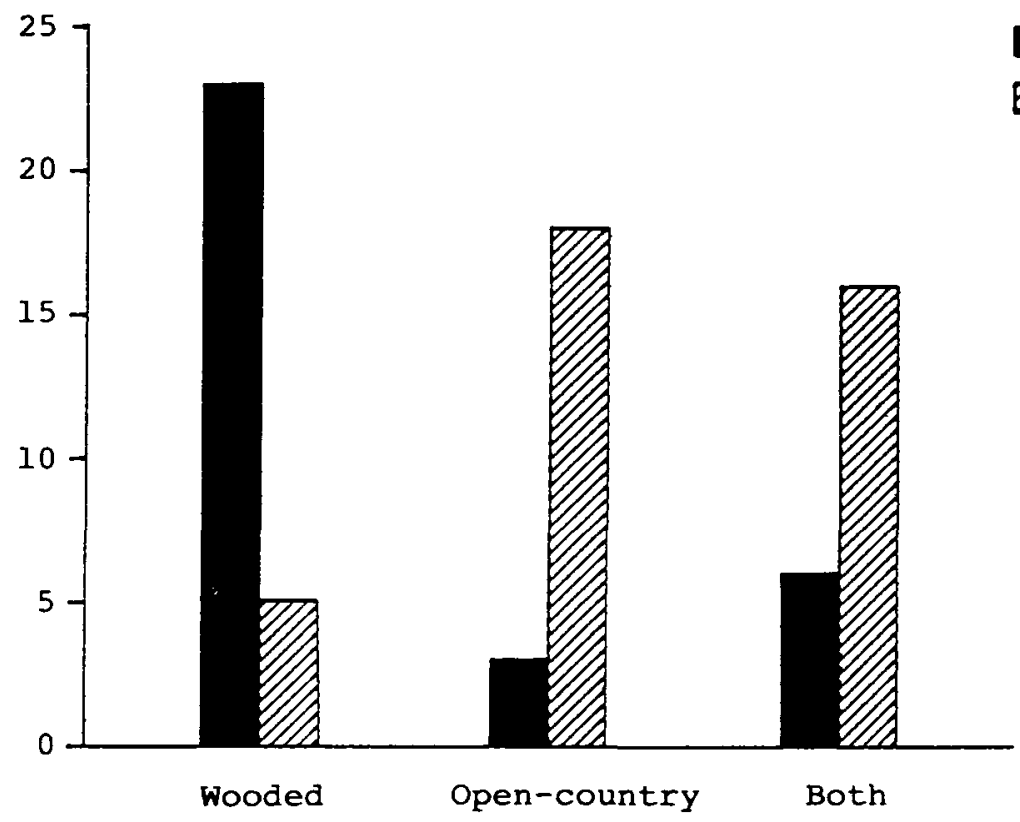

BIRD SPECIES

LMEF

Q non-LMEF

\section{HABITAT TYPE}

Figure 2. The number of species of birds identified by Wells (1985) to be dependent exclusively or extensively on lowland mixed evergreen forest (LMEF) and non-LMEF species in wooded (sites A, B and C), open-country (sites D, E and F) and both types of habitat.

Dicrurus macrocercus and Eurasian Tree Sparrow Passer montanus. These observations may suggest the beginnings of the colonization of open spaces around the wooded habitats by these non-LMEF species, and support the trend noted by Prentice and Aikanathan (1989) of the increasing proportion of birds in the peat-swamp forest that appeared to be adapted to colonizing open spaces. These new records increase the checklist of bird species in the North Selangor peatswamp forest from 174 (Prentice and Aikanathan 1989) to 180 . The Green Broadbill Calyptomena viridis, recorded by Marsh and Young (in Prentice and Aikanathan 1989) but not by Prentice and Aikanathan (1989), was sighted again in this study at site $C$.

Of the 70 species of birds recorded in this study, one, the Lesser Adjutant Leptoptilos javanicus, is listed as globally threatened (Collar and Andrew 1988). Under Malaysian law (the Protection of Wildlife Act 1972 and its latter amendments), a totally protected species cannot be hunted without a special licence whilst a protected species can be hunted or killed under licence or in self-defence (Kiew 1982). This legislation appeared to be an attempt to curb indiscriminate collecting and hunting of wildlife, stricter control of illegal traffic in wildlife and the protection of threatened species in West Malaysia (see Khan 
1988, Aiken and Leigh 1992). According to Kiew and Davison (1982), 38 of the 70 species of birds we recorded are totally protected and five have protected status under Malaysian law; together these 43 species represent $61 \%$ of the total number of bird species recorded in our survey. This proportion approximates to the percentage of protected and totally protected species for Malaysia as a whole (64\% or 457 of 717 species) (Kiew and Davison 1982). In addition, Kiew and Davison (1982) list 67 species that were considered vulnerable or endangered in Malaysia which are not protected by law. Thus whilst the protection status of the birds may not necessarily identify them as species most requiring conservation management in West Malaysia, their occurrence within the peatswamp forest and its surroundings may indicate its conservation value. Pons $e$ t al. (1988) have suggested that the North Selangor peat-swamp forest is particularly important as it is large enough to hold areas that may be conserved as representative natural wildlife communities. In addition, 16 forest species of bird found in the peat-swamp forest are listed as subregional endemics (Wells 1985) and their conservation would help in maintaining the diversity and uniqueness of the forests.

The presence of the nearby (but much smaller: 44 ha) Kuala Selangor Nature Park (see Figure 1), which comprises chiefly mangrove habitat, should not diminish the conservation value of the peat-swamp forest, at least where the avifauna is concerned. A comparison of the checklists of birds that have been compiled so far (Prentice and Aikanathan 1989, Malayan Nature Society unpublished), together with our new sightings, indicates little species overlap between them. A total of 180 and 157 species of birds have been reported from the North Selangor peat-swamp forest and Kuala Selangor Nature Park, respectively. Seventy-six species are common to both sites, 103 have only been recorded in the peat-swamp forest, and 80 have only been recorded at Kuala Selangor. The swiftlet Collocalia sp. not identified by Prentice and Aikanathan (1989) was excluded from this comparison, as was the White-bellied Swiftlet $C$. esculenta recorded in Kuala Selangor by the Malayan Nature Society (unpublished). Table I summarizes, according to families, the number of species which are not common to the two sites. It can be seen that the species found only in Kuala Selangor Nature Park are mainly wading and coastal birds. Species that are found only in the North Selangor peat-swamp forest are mainly forest species.

\section{Recommendations}

Based on our limited study of the swamp forest and its surroundings, the following recommendations are proposed for consideration.

The logged areas surrounding the forest sanctuary proposed by Prentice and Aikanathan (1989) (see Figure 1) should be properly managed to allow regeneration. These areas can serve as a buffer zone between newly logged areas and the sanctuary. Our observations suggest that regenerating forest, such as site A, contains a relatively good proportion of forest bird species and could be considered in a management proposal for the peat-swamp forest.

Our data indicate that the logging railway (site C) contained more LMEF species (comprising $55 \%$ of all species sighted at site C) than the logging track 
Table 1. The number of species listed according to family that have been recorded in the North Selangor peat-swamp forest and Kuala Selangor Nature Park. The classification of families follows King et al. (1975)

\begin{tabular}{|c|c|c|}
\hline \multirow[t]{2}{*}{ Family } & \multicolumn{2}{|c|}{ Number of species } \\
\hline & $\begin{array}{l}\text { North Selangor } \\
\text { peat-swamp forest }\end{array}$ & $\begin{array}{l}\text { Kuala Selangor } \\
\text { Nature Park }\end{array}$ \\
\hline Ardeidae & - & 11 \\
\hline Pandionidae & - & 1 \\
\hline Accipitridae & 1 & 1 \\
\hline Falconidae & 1 & - \\
\hline Phasianidae & I & - \\
\hline Rallidae & - & 4 \\
\hline Rostratulidae & - & 1 \\
\hline Charadriidae & - & 6 \\
\hline Scolopacidae & - & 17 \\
\hline Laridae & - & 6 \\
\hline Columbidae & 3 & 2 \\
\hline Psittacidae & 2 & - \\
\hline Cuculidae & 8 & 1 \\
\hline Tytonidae & 1 & 1 \\
\hline Strigidae & 3 & 1 \\
\hline Caprimulgidae & 1 & - \\
\hline Apodidae & 1 & 1 \\
\hline Hemiprocnidae & 2 & - \\
\hline Trogonidae & 2 & - \\
\hline Alcedinidae & 3 & - \\
\hline Bucerotidae & 4 & - \\
\hline Capitonidae & 6 & 1 \\
\hline Picidae & 8 & 2 \\
\hline Eurylaimidae & 5 & - \\
\hline Pittidae & - & 1 \\
\hline Campephagidae & 4 & 1 \\
\hline Chloropseidae & 4 & - \\
\hline Pycnonotidae & 6 & 1 \\
\hline Dicruridae & 2 & - \\
\hline Oriolidae & 2 & - \\
\hline Corvidae & 2 & I \\
\hline Paridae & - & 1 \\
\hline Sittidae & 1 & - \\
\hline Timaliidae & 13 & 1 \\
\hline Turdidae & 3 & - \\
\hline Sylviidae & - & 3 \\
\hline Muscicapidae & 5 & 2 \\
\hline Pachycephalidae & & 1 \\
\hline Motacillidae & 1 & 3 \\
\hline Artamidae & - & 1 \\
\hline Sturnidae & I & 3 \\
\hline Nectariniidae & 4 & - \\
\hline Dicaeidae & 4 & - \\
\hline Zosteropidae & - & 1 \\
\hline Ploceidae & - & 4 \\
\hline
\end{tabular}


at site D, where LMEF species made up about $26 \%$ of all species sighted. This suggests that log extraction by railway may be less damaging to the forest than log extraction by traxcovators. This observation requires further investigation, particularly as traxcovators are used to remove logs from the North Selangor peat-swamp forest to extraction routes such as canals, roads and railways (Prentice and Parish 1992).

Management of the area should aim at increasing public awareness of conservation issues. This may be done by setting aside certain non-sensitive areas in the logged forest to be developed for recreational activities, e.g. trekking, birdwatching, controlled angling, guided river cruises, etc. Suitable sites would be patches of regenerating forest similar to sites $A, B$ and $C$. The impact of such recreational activities on wildlife would have to be assessed before implementation. For instance, the existing volume of boat traffic for log extraction has been reported to cause disturbance to the Malayan false gharial Tomistoma schlegelii and estuarine crocodile Crocodylus porosus, and increased use of the river may further affect the survival of these species (Prentice and Aikanathan 1989).

Further studies should include detailed work on the population and behavi oural ecology of the various species of birds in the North Selangor peat-swamp forest, to aid the better assessment of the effects of habitat alteration on the avifauna. For instance, further research in the peat-swamp forest could gather data such as species richness, individual species abundance, biomass and indicator species which provide information on habitat quality (see Wong 1985).

\section{Acknowledgements}

The following students of the Zoology Honours Class were involved in this study: T. H. Chang, E. S. Chen, J. F. L. Chin, J. binte Hussein, C. Y. Lee, A. R. Sebastian, H. Ting, D. Tsi and L. K. Wang. We would like to thank I. M. Turner and C. Prentice for their constructive comments on the manuscript; C. M. Yang and staff of the Zoological Reference Collection (National University of Singapore), D. S. L. Ng, O. Y. Yap, A. Latiff, T. H. T. Tan and the Asian Wetlands Bureau (Malaysia). This study was part of the annual Honours field course and was partially funded by the National University of Singapore and research grant RP900359. 
Appendix. Distribution of bird species and numbers sighted at the six study sites at North Selangor peat-swamp forest.

Taxonomy and the principal habitat for each species follow Wells (1985). Habitat: F (forest); FE (forest edge); $\mathrm{M}$ (mangrove); $\mathrm{N}$ (not primarily forest). Lowland mixed evergreen forest (LMEF) includes $\mathrm{F}$ and FE species; non-LMEF includes $\mathrm{M}$ and $\mathrm{N}$ species. An unconfirmed sighting is denoted as (?); ${ }^{*}$ and ${ }^{* *}$ indicate protected and totally protected species respectively, as defined by Kiew and Davison (1982).

\begin{tabular}{|c|c|c|c|c|c|c|c|}
\hline \multirow[b]{2}{*}{ Species } & \multirow[t]{2}{*}{ Habitat } & \multicolumn{6}{|c|}{ Number counted at sites } \\
\hline & & A & B & $C$ & D & E & $\mathrm{F}$ \\
\hline $\begin{array}{l}\text { Little Heron } \\
\text { Butorides striatus }\end{array}$ & M & - & - & - & - & - & 3 \\
\hline $\begin{array}{l}\text { Yellow Bittern } \\
\text { lxobrychus sinensis }\end{array}$ & $\mathrm{N}$ & - & - & - & - & 1 & - \\
\hline $\begin{array}{l}\text { Cinnamon Bittern } \\
\text { Ixobrychus cinnamomeus }\end{array}$ & $\mathrm{N}$ & - & - & - & - & 4 & - \\
\hline $\begin{array}{l}\text { Lesser Adjutant } \\
\text { Leptoptilos javanicus }\end{array}$ & M & - & - & - & - & - & 1 \\
\hline $\begin{array}{l}\text { Crested Honey-buzzard** } \\
\text { Pernis ptilorhyncus }\end{array}$ & $\mathrm{N}$ & - & 1 & - & 1 & - & - \\
\hline $\begin{array}{l}\text { Black-shouldered Kite } \\
\text { Elanus caeruleus }\end{array}$ & N & - & - & - & - & 2 & 6 \\
\hline $\begin{array}{l}\text { Crested Serpent-eagle* } \\
\text { Spilomis cheela }\end{array}$ & $\mathrm{F}$ & - & 2 & - & - & - & - \\
\hline $\begin{array}{l}\text { Changeable Hawk-eagle* } \\
\text { Spizaetus cirrhafus }\end{array}$ & $\mathrm{FE}$ & - & - & - & - & - & 1 \\
\hline $\begin{array}{l}\text { Black-thighed Falconet } \\
\text { Microhierax fringillarius }\end{array}$ & $\mathrm{FE}$ & 5 & 2 & - & - & - & - \\
\hline $\begin{array}{l}\text { White-breasted Waterhen* } \\
\text { Amauromis phoenicurus }\end{array}$ & $\mathrm{N}$ & - & - & 1 & - & 2 & - \\
\hline $\begin{array}{l}\text { Pink-necked Green-pigeon* } \\
\text { Treron vernants }\end{array}$ & $N$ & 5 & - & - & - & - & - \\
\hline $\begin{array}{l}\text { Green Imperial-pigeon }{ }^{* *} \\
\text { Ducula aenea }\end{array}$ & $\mathrm{F}$ & 2 & - & 20 & - & - & - \\
\hline $\begin{array}{l}\text { Rock Pigeon } \\
\text { Columba livia }\end{array}$ & $N$ & - & - & - & 3 & - & 2 \\
\hline $\begin{array}{l}\text { Spotted Dove } \\
\text { Streptopelia chinensis }\end{array}$ & $N$ & 2 & - & - & 3 & - & 2 \\
\hline $\begin{array}{l}\text { Peaceful Dove } \\
\text { Geopelia striata }\end{array}$ & $N$ & - & - & - & 2 & - & 1 \\
\hline $\begin{array}{l}\text { Long-tailed Parakeet } \\
\text { Psittacula longicauda }\end{array}$ & $\mathrm{F}$ & 48 & - & - & - & 2 & 16 \\
\hline $\begin{array}{l}\text { Blue-crowned Hanging Parrot } \\
\text { Loriculus galgulus }\end{array}$ & $\mathrm{F}$ & 7 & - & - & - & - & - \\
\hline $\begin{array}{l}\text { Plaintive Cuckoo** } \\
\text { Cacomantis merulinus }\end{array}$ & $\mathrm{N}$ & - & - & - & - & 2 & - \\
\hline $\begin{array}{l}\text { Chestnut-bellied Malkoha } \\
\text { Phaenicophaeus sumatranus }\end{array}$ & F & - & - & 1 & - & $\cdot$ & - \\
\hline $\begin{array}{l}\text { Red-billed Malkoha** } \\
\text { Phaenicophaeus javanicus }\end{array}$ & $\mathrm{F}$ & 1 & - & - & - & - & - \\
\hline $\begin{array}{l}\text { House Swift } \\
\text { Aptis affinis }\end{array}$ & $\mathrm{N}$ & 15 & 14 & 8 & - & 56 & 45 \\
\hline $\begin{array}{l}\text { Whiskered Treeswift } \\
\text { Hemiprocne comata }\end{array}$ & $\mathrm{F}$ & 5 & - & - & 1 & - & - \\
\hline
\end{tabular}




\begin{tabular}{|c|c|c|c|c|c|c|c|}
\hline \multirow[b]{2}{*}{ Species } & \multirow[t]{2}{*}{ Habitat } & \multicolumn{6}{|c|}{ Number counted at sites } \\
\hline & & A & B & $\mathrm{C}$ & $\mathrm{D}$ & E & $\mathrm{F}$ \\
\hline $\begin{array}{l}\text { Common Kingfisher** } \\
\text { Alcedo atthis }\end{array}$ & $\mathrm{N}$ & - & 1 & - & - & - & - \\
\hline $\begin{array}{l}\text { White-throated Kingfisher } \\
\text { Halcyon smyrnensis }\end{array}$ & $\mathrm{N}$ & 1 & 16 & - & 15 & 9 & 10 \\
\hline $\begin{array}{l}\text { Collared Kingfisher** } \\
\text { Halcyon chloris }\end{array}$ & M & - & - & 1 & - & 1 & - \\
\hline $\begin{array}{l}\text { Dollarbird }{ }^{* *} \\
\text { Eurystomus orientalis }\end{array}$ & $\mathrm{FE}$ & - & 2 & 4 & 1 & - & 2 \\
\hline $\begin{array}{l}\text { Black Hornbill }{ }^{* *} \\
\text { Anthracoceros malayanus }\end{array}$ & $\mathrm{F}$ & 2 & - & - & - & - & - \\
\hline $\begin{array}{l}\text { Rhinoceros Hornbill** } \\
\text { Buceros rhinoceros }\end{array}$ & $\mathrm{F}$ & 3 & 1 & - & - & - & - \\
\hline $\begin{array}{l}\text { Brown Barbet } \\
\text { Calorhamphus fuliginosus }\end{array}$ & F & 1 & - & - & - & - & - \\
\hline $\begin{array}{l}\text { Banded Woodpecker** } \\
\text { Picus miniaceus }\end{array}$ & $\mathrm{F}$ & - & - & 3 & - & - & - \\
\hline $\begin{array}{l}\text { Great Slaty Woodpecker** } \\
\text { Muelleripicus pulverulentus }\end{array}$ & $F$ & - & & - & - & - & 3 \\
\hline $\begin{array}{l}\text { Black-and-red Broadbill**} \\
\text { Cymbirhynchus macrorhynchus }\end{array}$ & $\mathrm{FE}$ & - & - & - & 1 & - & - \\
\hline $\begin{array}{l}\text { Black-and-yellow Broadbill } \\
\text { Eurylaimus ochromalus }\end{array}$ & $F$ & - & - & $I$ & - & - & - \\
\hline $\begin{array}{l}\text { Green Broadbill** } \\
\text { Calyptomena viridis }\end{array}$ & $\mathrm{F}$ & - & - & 1 & - & - & - \\
\hline $\begin{array}{l}\text { Pacific Swallow** } \\
\text { Hirundo tahitica }\end{array}$ & $\mathrm{N}$ & 4 & - & - & 1 & 5 & 56 \\
\hline $\begin{array}{l}\text { Green Iora** } \\
\text { Aegithina viridissima }\end{array}$ & $\mathrm{F}$ & 20 & - & 8 & - & - & - \\
\hline $\begin{array}{l}\text { Lesser Green Leafbird** } \\
\text { Chloropsis cyanopogon }\end{array}$ & $F$ & 5 & - & - & - & - & $\cdot$ \\
\hline $\begin{array}{l}\text { Blue-winged Leafbird }{ }^{* *} \\
\text { Chloropsis cochinchinensis }\end{array}$ & $\mathrm{F}$ & 7 & - & - & - & - & - \\
\hline $\begin{array}{l}\text { Yellow-vented Bulbul } \\
\text { Pycnonotus goiavier }\end{array}$ & $\mathrm{N}$ & 1 & 2 & 1 & 4 & 6 & 5 \\
\hline $\begin{array}{l}\text { Olive-winged Bulbul** } \\
\text { Pycnonotus plumosus }\end{array}$ & $\mathrm{N}$ & 8 & - & 11 & 3 & - & - \\
\hline $\begin{array}{l}\text { Cream-vented Bulbul }{ }^{* *} \\
\text { Pycnonotus simplex }\end{array}$ & $\mathrm{F}$ & 10 & 8 & 2 & - & - & - \\
\hline $\begin{array}{l}\text { Black Drongo } \\
\text { Dicrurus macrocercus }\end{array}$ & $\mathrm{N}$ & 1 & - & 1 & - & - & - \\
\hline $\begin{array}{l}\text { Greater Racket-tailed Drongo** } \\
\text { Dicrurus paradiseus }\end{array}$ & $\mathbf{F}$ & - & $I$ & 1 & - & - & - \\
\hline $\begin{array}{l}\text { Black-naped Oriole } \\
\text { Oriolus chinensis }\end{array}$ & $\mathrm{N}$ & 1 & - & 1 & 4 & - & 1 \\
\hline $\begin{array}{l}\text { Asian Fairy Bluebird }{ }^{* *} \\
\text { Irena puella }\end{array}$ & $\mathrm{N}$ & 3 & - & - & - & - & - \\
\hline $\begin{array}{l}\text { House Crow } \\
\text { Corvus splendens }\end{array}$ & $\mathrm{N}$ & - & - & - & - & - & 2 \\
\hline $\begin{array}{l}\text { Large-billed Crow } \\
\text { Corous macrorhynchos }\end{array}$ & $N$ & 1 & - & - & - & 5 & 3 \\
\hline $\begin{array}{l}\text { Short-tailed Babbler(?)** } \\
\text { Trichastoma malaccense }\end{array}$ & $\mathrm{F}$ & 1 & - & - & - & - & - \\
\hline
\end{tabular}




\begin{tabular}{|c|c|c|c|c|c|c|c|}
\hline \multirow[b]{2}{*}{ Species } & \multirow[t]{2}{*}{ Habitat } & \multicolumn{6}{|c|}{ Number counted at sites } \\
\hline & & A & $\mathrm{B}$ & $\mathrm{C}$ & $\mathrm{D}$ & E & 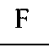 \\
\hline $\begin{array}{l}\text { Moustached Babbler** } \\
\text { Malacopteron magnirostre }\end{array}$ & F & 1 & - & - & - & - & - \\
\hline $\begin{array}{l}\text { Striped Tit-babbler** } \\
\text { Macronous gularis }\end{array}$ & $\mathrm{FE}$ & 8 & - & 2 & 1 & - & - \\
\hline $\begin{array}{l}\text { Magpie Robin } \\
\text { Copsychus saularis }\end{array}$ & $N$ & 8 & 6 & 5 & 1 & 3 & 5 \\
\hline $\begin{array}{l}\text { White-rumped Shama** } \\
\text { Copsychus malabaricus }\end{array}$ & $\mathrm{F}$ & 2 & 1 & - & 1 & - & - \\
\hline $\begin{array}{l}\text { Flyeater* }^{* *} \\
\text { Gerygone sulphurea }\end{array}$ & F & 2 & - & - & - & - & - \\
\hline $\begin{array}{l}\text { Arctic Warbler** } \\
\text { Phylloscopus borealis }\end{array}$ & $\mathrm{F}$ & 3 & - & - & - & - & - \\
\hline $\begin{array}{l}\text { Common Tailorbird } \\
\text { Orthotomus sutorius }\end{array}$ & $\mathrm{N}$ & - & - & $x$ & 2 & - & - \\
\hline $\begin{array}{l}\text { Yellow-bellied Prinia** } \\
\text { Prinia flaviventris }\end{array}$ & $N$ & - & 3 & - & 1 & 1 & 3 \\
\hline $\begin{array}{l}\text { Pied Fantail } \\
\text { Rhipidura javanica }\end{array}$ & M & - & - & - & - & 2 & - \\
\hline $\begin{array}{l}\text { Philippine Glossy Starling } \\
\text { Aplonis panayensis }\end{array}$ & $\mathrm{N}$ & - & - & - & - & 1 & - \\
\hline $\begin{array}{l}\text { Common Myna } \\
\text { Acridotheres tristis }\end{array}$ & $N$ & - & - & $\cdot$ & 19 & 41 & 89 \\
\hline $\begin{array}{l}\text { Jungle Myna } \\
\text { Acridotheres fuscus }\end{array}$ & $\mathrm{N}$ & - & - & - & 12 & 9 & 14 \\
\hline $\begin{array}{l}\text { Hill Myna* } \\
\text { Gracula religiosa }\end{array}$ & $\mathrm{F}$ & 18 & 15 & 2 & - & - & - \\
\hline $\begin{array}{l}\text { Olive-backed Sunbird** } \\
\text { Nectarinia jugularis }\end{array}$ & $\mathrm{M}$ & 3 & - & - & - & 1 & - \\
\hline $\begin{array}{l}\text { Yellow-vented Flowerpecker** } \\
\text { Dicaeum chrysorrheum }\end{array}$ & $\mathrm{FE}$ & 8 & - & - & - & - & - \\
\hline $\begin{array}{l}\text { Orange-bellied Flowerpecker** } \\
\text { Dicaeum trigonostigma }\end{array}$ & $\mathrm{FE}$ & I & - & - & 1 & - & - \\
\hline $\begin{array}{l}\text { Eurasian Tree Sparrow } \\
\text { Passer montanus }\end{array}$ & $\mathrm{N}$ & 12 & - & - & 8 & 2 & 19 \\
\hline $\begin{array}{l}\text { Baya Weaver } \\
\text { Ploceus philippinus }\end{array}$ & $\mathrm{N}$ & - & - & - & 31 & 1 & - \\
\hline $\begin{array}{l}\text { White-rumped Munia } \\
\text { Lonchura striata }\end{array}$ & $N$ & - & - & $\cdot$ & - & - & 1 \\
\hline $\begin{array}{l}\text { Javan Munia } \\
\text { Lonchura leucogastroides }\end{array}$ & $\mathrm{N}$ & - & - & - & - & - & 1 \\
\hline $\begin{array}{l}\text { Chestnut Munia } \\
\text { Lonchura malacca }\end{array}$ & $\mathrm{N}$ & - & - & - & 6 & 2 & - \\
\hline $\begin{array}{l}\text { White-headed Munia } \\
\text { Lonchura maja }\end{array}$ & $\mathrm{N}$ & - & - & - & - & 1 & - \\
\hline
\end{tabular}




\section{References}

Aiken, S. R. and Leigh, C. H. (1992) Vanishing rain forests: the ecological transition in Malaysia. Oxford: Clarendon Press.

Collar, N. J. and Andrew, P. (1988) Birds to watch: the ICBP world checklist of threatened birds. Cambridge, U.K.: International Council for Bird Preservation (Techn. Publ. 8).

Davies, J. and Abdullah, A. R. (1989) Freshwater fish survey of the North Selangor peat-swamp forest. Kuala Lumpur: Asian Wetland Bureau (Publ. 46).

Khan, M. M. K. (1988) Animal conservation strategies. Pp. 251-272 in Earl of Cranbrook, ed. Key environments: Malaysia. Oxford: Pergamon Press.

Kiew, B. H. (1982) Conservation status of the Malaysian fauna. I. Mammals. Malay. Nat. 35(3): 3-19.

Kiew, B. H. and Davison, G. (1982) Conservation status of the Malaysian fauna. II. Birds. Malay. Nat. 36(2): 2-25, 28-34.

King, B. F., Dickinson, E. C. and Woodcock, M. W. (1975) A field guide to the birds of South-East Asia. London: Collins.

MacKinnon, J. and MacKinnon, K. (1986) Review of the protected areas system in the IndoMalayan Realm. Gland, Switzerland, and Cambridge, U.K.: International Union for Conservation of Nature and Natural Resources.

Malayan Nature Society (unpublished) Checklist of birds at Kuala Selangor Nature Park. Kuala Lumpur: Malayan Nature Society.

Pons, L. J., Prentice, C. and Aikanathan, S. (1988) A preliminary assessment of two peat swamps in Selangor state, Peninsular Malaysia, in relation to their optimal use. Kuala Lumpur: Asian Wetland Bureau (Publ. 30).

Prentice, C. and Aikanathan, S. (1989) A preliminary faunal survey of the North Selangor peat-swamp forest. Kuala Lumpur: Asian Wetland Bureau (Report $46 \mathrm{~d}$ ).

Prentice, C. and Parish, D. (1992). Conservation of peat-swamp forests: a forgotten ecosystem. Malay. Nat. J. 45: 128-144.

Wells, D. R. (1985) The forest avifauna of Western Malesia and its conservation. Pp.213232 in A. W. Diamond and T. E. Lovejoy, eds. Conservation of tropical forest birds. Cambridge, U.K.: International Council for Bird Preservation (Techn. Publ. 4).

Whitmore, T. C. (1986) Tropical rain forests of the Far East. Second edition. Oxford: Oxford University Press.

Wong, M. (1985) Understory birds as indicators of regeneration in a patch of selectively logged West Malaysian rain forest. Pp.249-263 in A. W. Diamond and T. E. Lovejoy, eds. Conservation of tropical forest birds. Cambridge, U.K.: International Council for Bird Preservation (Techn. Publ. 4).

Wyatt-Smith, J. (1959) Peat Swamp forests in Malaya. Malay. Forester 24: 110-121.

KANG NEE

LEE PHENG GUAN

Department of Zoology, National University of Singapore, Kent Ridge, Singapore 0511 